\title{
A new species of Smicridea McLachlan (Trichoptera:Hydropsychidae) from Venezuela and its role in travertine biogenesis
}

\author{
Henrique Paprocki ${ }^{1}$, RALPH W. Holzenthal \\ Department of Entomology, University of Minnesota, 1980 Folwell Avenue, \\ St. Paul, Minnesota 55108 USA
}

\section{Claudia CREssa}

\author{
Instituto de Zoología Tropical, Universidad Central de Venezuela, 1041-A Caracas, Venezuela
}

\begin{abstract}
We collected an undescribed hydropsychid caddisfly, Smicridea (Smicridea) travertinera, $\mathrm{n}$. sp., from 2 sites in Venezuela. One of the sites, Quebrada El Charo, flowed over extensive calcareous formations of travertine, which were covered with retreats and capture nets of the new species. Smicridea travertinera was the most abundant aquatic insect colonizing travertine. We describe the adult male, the retreat and net, and gut contents. The retreat consisted of an aperture in the travertine with a capture net. Retreat-making behavior appears to cause both the biogenesis and erosion of the travertine formations.
\end{abstract}

Key words: Smicridea, Hydropsychidae, Trichoptera, travertine, Venezuela, taxonomy, systematics, biogenesis, retreat-making behavior, gut contents.

Travertines are composed of calcareous sediments, chemically or biologically precipitated from waters of karstic, geothermal, or artesian origin, which are supersaturated with $\mathrm{CO}_{2}$ (Drysdale 1999, Fig. 1A). In such conditions, $\mathrm{CO}_{2}$ rapidly outgasses to the atmosphere and $\mathrm{CaCO}_{3}$ precipitates out of solution as calcite or aragonite. This precipitate can cover all available inorganic and organic substrates, such as rocks, leaves, twigs, and also caddisfly cases and retreats (Fig. 1B-D). Deposition of travertines can be highly influenced by living organisms. The biogenesis of travertines has been widely studied, but mostly through the activity of diatoms and bacteria (Pentecost et al. 1997). Few researchers have studied the role of other aquatic biota in travertine formation.

Aquatic insects can influence both deposition and erosion of travertines (Thienemann 1933, Drysdale 1999). Drysdale (1998) reported that aquatic insect larvae play direct and indirect geomorphological roles in the deposition of travertines in the Barkly Karst, Australia. He demonstrated that species of Cheumatopsyche (Hydropsychidae) were the dominant members of the aquatic fauna on the surface of travertines

\footnotetext{
${ }^{1}$ Winner of the Hydrolab Student Award for the Best Poster Presentation in Basic or Applied Research at the $50^{\text {th }}$ Annual NABS Meeting, Pittsburgh, Pennsylvania, 27 May-1 June 2002. E-mail address: papr0002@umn.edu
}

where strong currents prevail. These caddisflies constructed cylindrical retreats with capture nets on the travertine surface, which became important substrates for $\mathrm{CaCO}_{3}$ deposition (Drysdale 1998). Other important studies on travertine biogenesis include Drysdale (2001) on the hydrochemistry of a travertine-depositing stream in Australia, Freytet and Verrecchia (1995) on Ca crystals associated with fungi in travertines, Pentecost et al. (1997) on the influence of phototrophic microorganisms on travertine deposition, and Humphreys et al. (1995) on aquatic insect biogenesis of freshwater tufa dams.

Among the caddisflies, members of the family Hydropsychidae have the greatest potential to influence travertine deposition. Hydropsychid larvae construct fixed retreats with silken capture nets that provide a suitable surface area for $\mathrm{CaCO}_{3}$ precipitation. We describe a new species in the hydropsychid genus Smicridea, subgenus Smicridea McLachlan, from Venezuela, the larvae of which inhabit travertine formations. We also discuss aspects of the biology of this species and its influence on biogenesis of travertine formations.

The genus Smicridea is widespread in the Neotropical realm where 162 species occur, 16 of which have been recorded from Venezuela (Flint et al. 1999). Known Smicridea larvae build typical hydropsychid retreats and capture nets 

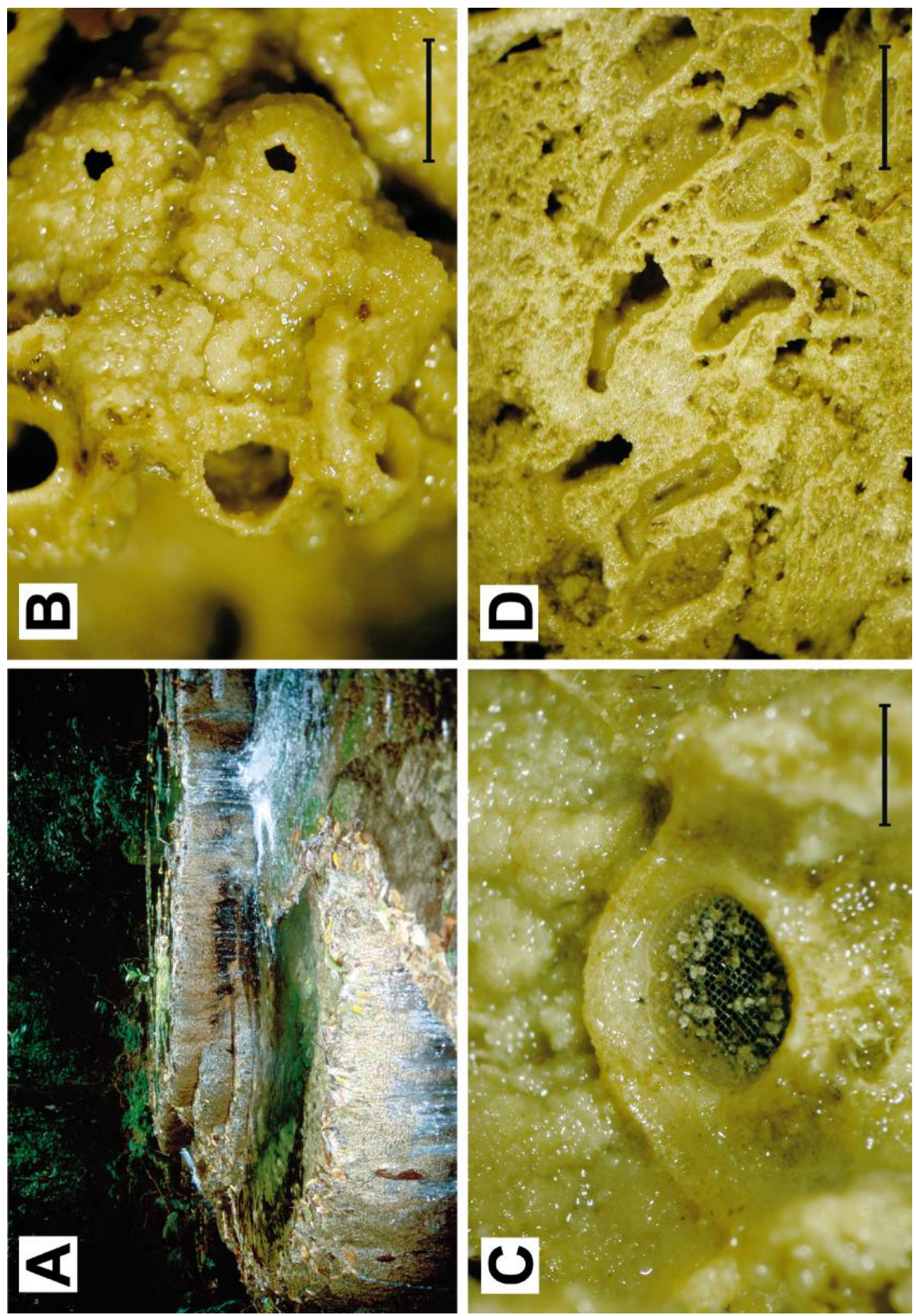

This content downloaded from 134.084.028.154 on June 21, 2017 07:47:01 AM All use subject to University of Chicago Press Terms and Conditions (http://www.journals.uchicago.edu/t-and-c). 
(Wiggins 1996); none have been reported previously from travertine formations. Previous descriptions of larvae and pupae of Smicridea are found in Correa et al. (1981), Flint (1974, 1989), and Wiggins (1996). Adult taxonomic works include Flint (1974) on the North and Central American species, Flint (1989) on the Chilean fauna, and Blahnik (1995) on the fasciatella complex.

\section{Methods}

\section{Study area}

We collected the new Smicridea species from 2 streams in the northwestern Venezuelan state of Lara within or near Parque Nacional Cueva de la Quebrada del Toro (see Gabaldón 1987, 1992 for description of the park). The undisturbed vegetation in the region consists of dense, humid, pre-montane forest. The canopy shades most of the riverbed, and contains mostly Erythrina poeppigiana (Fabaceae:Papilionoideae), Roystonea regia (Arecaceae), Trichilia hirta (Meliaceae), Tabebuia rosea (Bignoniaceae), and Bauhinia spp. (Fabaceae:Caesalpinioideae). The geology of the region is characterized by a number of Cenozoic faults, with limestone bedrock forming the main component. The rainy season lasts $\sim 7$ to 8 mo (May to November) with mean annual precipitation ranging from 1100 to 2200 $\mathrm{mm}$. Water dissolves the limestone to produce deep fissures and sinkholes, and percolates through fissures contributing to a network of karst. Average annual minimum and maximum temperatures in the area are 18 and $24^{\circ} \mathrm{C}$, respectively.

We collected adult caddisflies at 2 sites, Quebrada El Toro, within the National Park (lat $10^{\circ} 49.581^{\prime} \mathrm{N}$, long $69^{\circ} 07.990^{\prime} \mathrm{W}$ ), and nearby Quebrada El Charo (lat 10 $46.771^{\prime} \mathrm{N}$, long $69^{\circ} 12.174^{\prime}$ W). The Quebrada El Charo site consists of a series of emerald-green pools alternating with travertine barrages (Fig. 1A). We classified these travertines as meteogene travertines (Pentecost and Viles 1994). A 70-m high water-
TABLE 1. Physicochemical parameters of stream water at Quebrada El Toro and Quebrada El Charo, Estado Lara, Venezuela, measured at $1800 \mathrm{~h}$ on 11 and 12 June 2001, respectively.

\begin{tabular}{lcc}
\hline \hline \multicolumn{1}{c}{ Parameter } & $\begin{array}{c}\text { Quebrada } \\
\text { El Toro }\end{array}$ & $\begin{array}{c}\text { Quebrada } \\
\text { El Charo }\end{array}$ \\
\hline Air temperature $\left({ }^{\circ} \mathrm{C}\right)$ & 26.90 & 26.60 \\
Water temperature & & \\
$\quad\left({ }^{\circ} \mathrm{C}\right)$ & 22.50 & 24.30 \\
$\mathrm{pH}$ & 8.10 & 8.10 \\
$\mathrm{O}_{2}(\mathrm{mg} / \mathrm{L})(\%$ of & & \\
$\quad$ saturation) & $7.15(83.0)$ & $6.92(84.3)$ \\
$\mathrm{Conductivity}(\mu \mathrm{S} / \mathrm{cm})$ & 468.80 & 608.00 \\
$\mathrm{Ca}(\mathrm{mg} / \mathrm{L})$ & 61.60 & 31.70 \\
$\mathrm{Mg}(\mathrm{mg} / \mathrm{L})$ & 4.73 & 7.02 \\
$\mathrm{Na}(\mathrm{mg} / \mathrm{L})$ & 7.60 & 11.62 \\
$\mathrm{~K}(\mathrm{mg} / \mathrm{L})$ & 0.47 & 0.73 \\
$\mathrm{Cl}(\mathrm{mg} / \mathrm{L})$ & 14.10 & 13.00 \\
$\mathrm{SO}(\mathrm{mg} / \mathrm{L})$ & 16.00 & 30.00 \\
\hline
\end{tabular}

fall occurs $\sim 250 \mathrm{~m}$ upstream from the collecting site, just downstream from a large spring that forms the headwaters. We visited the site in June, just prior to the rainy season (delayed in 2001). Stream flow was at bankfull, suggesting that Quebrada El Charo is a perennial stream. Physicochemical parameters of the stream water for both sites are shown in Table 1.

\section{Specimen collection and preparation}

Adults were primarily attracted to an ultraviolet light placed in front of a white bed sheet and adjacent to the river; additional adults were netted during the day. Adults were collected individually in potassium cyanide kill jars and subsequently pinned. Larvae and pupae were removed from the travertine, and 2 travertine sections (range 140-850 $\mathrm{cm}^{3}$ ) were removed from the upper part of a barrage for examination of larval retreats in the laboratory.

Male and female genitalia were cleared in lactic acid for 10 to $30 \mathrm{~min}$ at $125^{\circ} \mathrm{C}$, and then rinsed in distilled water; remaining soft tissues were removed from the genitalia with fine-

FIG. 1. Smicridea travertinera habitat and retreat. A.-Travertine formations at Quebrada El Charo, Estado Lara, Venezuela. B.-Retreat of $S$. travertinera (scale bar $=2.7 \mathrm{~mm}$ ). C.-Anterior opening of retreat showing peripheral lip (scale bar $=0.8 \mathrm{~mm}$ ). D.-Cross section of travertine matrix showing larval tunnels (scale bar $=$ $7 \mathrm{~mm})$. 
tipped forceps. Genitalia were examined in watch glasses with glycerin under an Olympus ${ }^{\circledR}$ SZX 12 stereomicroscope (up to $216 \times$ ). Pencil drawings were made using a $10 \times 10 \mathrm{~mm}$ ocular grid via transfer to $2.5 \times 2.5 \mathrm{~cm}$ grid drawing paper. Drawings were then scanned, and final illustrations of male genitalia were made using Adobe Illustrator $9.0^{\circledR}$. Terminology for male genitalic structures follows Schmid (1998). Adults and larvae were associated using the metamorphotype method (Wiggins 1996).

We assessed larval diet by removing the digestive tract from 4 th instars $(n=10)$. Digestive tracks were placed in alcohol and shredded. Gut contents were then examined using an Olympus ${ }^{\circledR}$ BH-2 compound microscope (up to $500 \times$ ). Pieces of capture nets also were examined microscopically and photographed with a digital camera attached to the stereomicroscope. Digital images were imported into Auto-Montage ${ }^{\circledR}$ (Syncroscopy, Frederick, Maryland) and then measured using the "Measure Length" command.

Type material of the new species described was deposited in the University of Minnesota Insect Collection, St. Paul, Minnesota (UMSP), National Museum of Natural History, Smithsonian Institution, Washington, DC (NMNH), and the Instituto de Zoología Agrícola, Maracay, Venezuela (IZAM).

\section{Smicridea travertinera new species}

Figs 2-10

\section{Diagnosis}

Morphology of male genitalia of $S$. travertinera is similar to S. (Smicridea) riita Flint 1981; however, some diagnostic differences occur. In the new species the phallus is straighter (Fig. 3) and the apical sclerites differ from those in S. riita. In $S$. travertinera the apical phallic sclerites consist of a pair of dorsolateral plates, including an internal sclerite with its apex curved downward and with the dorsolateral plate connecting the dorsal and ventral arms (Figs 3,5). In addition, the inferior appendages are broader in $S$. travertinera (Figs 2, 6). The forewing has 2 transverse bands of white setae and an apical fringe of white setae. The mesodorsal surface of the head contains a small patch of white setae. The holotype of S. riita is completely fuscous, showing no wing pattern and no white spot on the head. However, an additional series of $S$. riita specimens examined from another Venezuelan locality displayed a range of variation from highly patterned, as in S. travertinera, to indistinctly patterned.

\section{Description}

Adult.-Length of forewing 4-6 mm. Head flattened dorsally, with round patch of white setae on mesodorsal surface. Antennae and thorax fuscous. Forewing color fuscous, with an apical fringe of white setae (easily rubbed off), and with 2 transverse bands of white setae, the $1^{\text {st }}$ band occurring at the basal $3^{\text {rd }}$, and the $2^{\text {nd }}$ band at the apical $3^{\text {rd }}$ of the forewing. Legs fuscous, with tarsi of fore and midlegs silvery. Abdomen fuscous.

Male genitalia (Figs 2-6). - Segment IX roughly triangular when viewed laterally, anterior margin slightly produced medially, posterior margin slightly sinuous, excavated basally; sternum IX narrow. Segment $X$ subrectangular, broad basally, tapering to broad, slightly transverse truncate apices; lateral margin rounded, setose; tergum $\mathrm{X}$ membranous at base, medially with pair of membranous dorsolateral ridges bordering deeply excavated area; surfaces covered with minute setae. Inferior appendage 2-segmented, tubularly elongate, basal segment straight, slightly inflated apically, apical segment short with apex rounded, slightly curved medially. Phallus tubular, angled from base, slightly enlarged apically; apex membranous ventrally, with pair of dorsolateral plates; internal sclerite with apex curved downward, with dorsolateral plate connecting the dorsal and ventral arms.

Larva (Figs 7-10).-Length 5-7 mm. Head dark brown, circular in dorsal view, flattened dorsally, with distinct U-shaped marginal carina. Frontoclypeal apotome broad anteriorly, almost reaching carina posteriorly, coronal suture short; ventral margin of head broadly notched posteromesally, ventral apotome triangular. Notum of each thoracic segment sclerotized; pronotum dark, divided on midline; meso- and metanota entire, lighter in color. Foretrochantin simple. Legs similar, although prothoracic leg somewhat shorter than meso- and metathoracic legs. Abdomen covered with flattened, scalelike setae and long setae (patterned as in Fig. 8), without lateral fringe; ventral gills with bulbous 

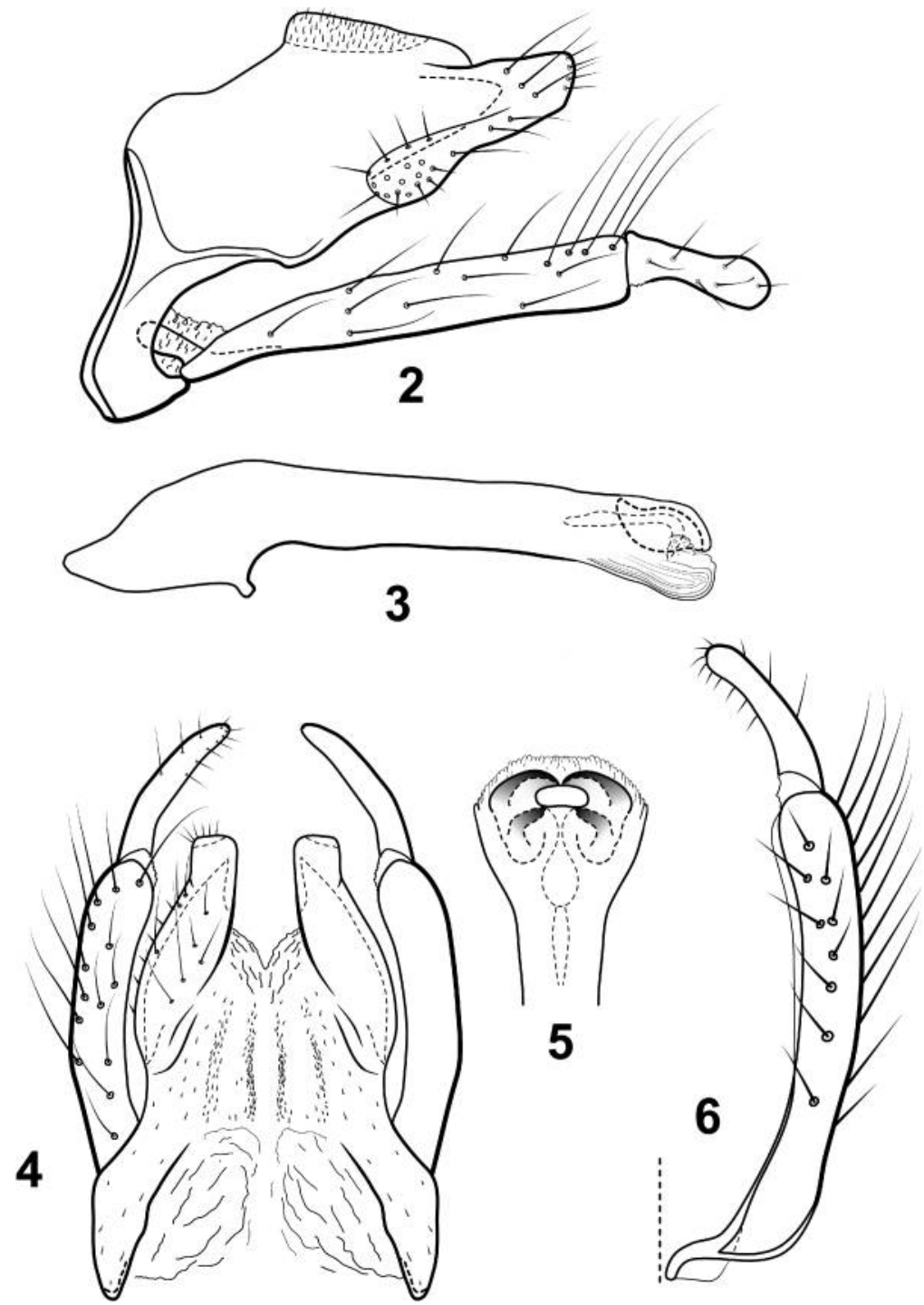

FIGS 2-6. Male genitalia of Smicridea travertinera, n. sp. 2.-Abdominal segments IX and X (lateral view). 3.-Phallus (lateral view). 4.- Abdominal segments IX and X (dorsal view). 5.- Phallus apex (dorsal view). 6.--Inferior appendage (ventral view).

base bearing 1-4 filaments, extending from thoracic segment II to abdominal segment VI; ventrolateral gills with 3-5 filaments on abdominal segments I-VII; lateral gills reduced, extending from abdominal segments III-VII. Abdominal sternum VIII with trapezoidal sclerite bearing numerous setae; sternum IX with 2 triangular sclerites bearing numerous setae; segment $X$ with conical membranous projection dorsally; anal prolegs with subrectangular lateral sclerite narrowing anteriorly and projecting dorsally; setal tuft on anal proleg bearing 5 long mesal and 5 long lateral setae, setal length not exceeding $2 \times$ length of anal proleg.

Larval retreat (Fig. 1B-D). - Length up to 7 $\mathrm{mm}$, consisting of an elongate-oval, domeshaped amalgamation of travertine particles fixed to the travertine matrix (Fig. 1B); anterior opening circular, 893.3-1025 $\mu \mathrm{m}$ in diameter (mean $=923, n=10$, Fig. 1C), with silken capture net covering opening, often with peripheral lip of travertine particles (Fig. 1C); small orifice 


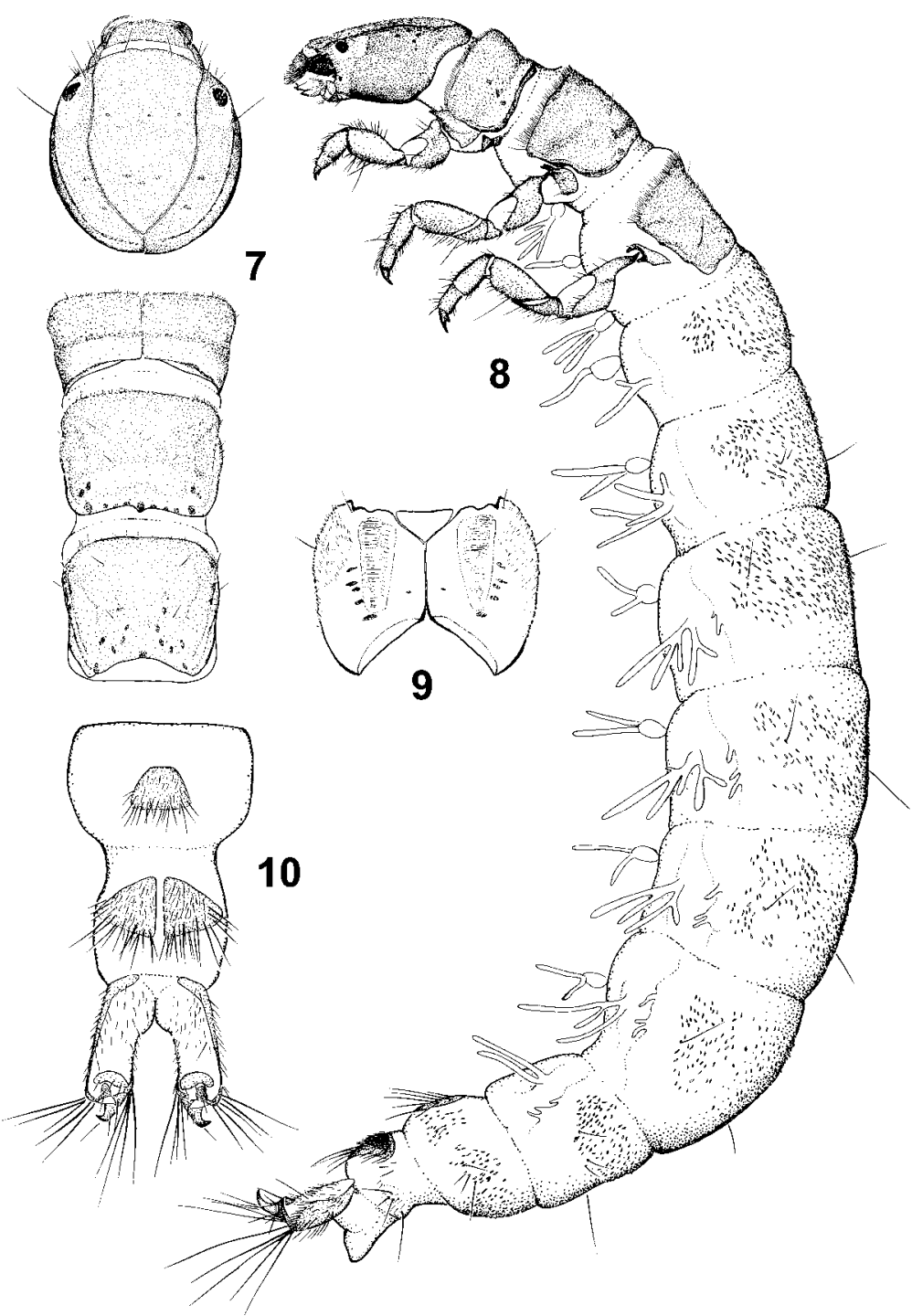

Figs 7-10. Larva of Smicridea travertinera, n. sp. 7.- - Head and thorax (dorsal view). 8.- Lateral view. 9.Head (ventral view). 10.-Abdominal segments VIII-X and abdominal prolegs (ventral view).

at posterior end, 240.4-360.8 $\mu \mathrm{m}$ in diameter (mean $=302.3, n=10$, Fig. 1B), often with accessory opening internally at retreat bottom; mesh size of net ranging from $30.8 \times 41.2 \mu \mathrm{m}$ to $42.2 \times 43.8 \mu \mathrm{m}($ mean $=38.6 \times 43.0 \mu \mathrm{m}, n$ $=20)$.

\section{Material examined}

Holotype: VENEZUELA, Falcón: Quebrada El Charo at cataratas, $10^{\circ} 46.771^{\prime} \mathrm{N}, 69^{\circ} 12.174^{\prime}$
W, el. 425 m, 12.vi.2001, R. W. Holzenthal, R. J. Blahnik, H. Paprocki, \& C. Cressa-1 ô (UMSP) (pinned). Paratypes: Same, 10 $\hat{0}, 2$ (UMSP) (pinned), 2 ô, 1 क (NMNH) (pinned); Parque Nacional Cueva de la Quebrada del Toro, Quebrada del Toro, $10^{\circ} 49.581^{\prime} \mathrm{N}, 69^{\circ} 07.990^{\prime} \mathrm{W}$, el. 530 m, 11.vi.2001, R. W. Holzenthal, R. J. Blahnik, H. Paprocki, \& C. Cressa-4 ô (UMSP) (pinned), 2 ô, 1 \& (IZAM) (pinned). Other material studied [VENEZUELA], Falcón: Quebrada El Charo at cataratas, $10^{\circ} 46.771^{\prime} \mathrm{N}$, 
69²12.174' W, el. 425 m, 12.vi.2001, R. W. Holzenthal, R. J. Blahnik, H. Paprocki, \& C. Cressa78 larvae (UMSP) (in alcohol).

\section{Etymology}

A travertine builder in Spanish would be a "travertinera", referring to the biogenesis of the travertine formations at the type locality.

\section{Biology}

In Quebrada El Charo, the surfaces of the travertine barrages were mostly covered by retreats of S. travertinera (Fig. 1A). Other aquatic insects were found in lower densities, including Diptera (Chironomidae), Ephemeroptera (Baetidae), Coleoptera (Elmidae), and Trichoptera (Helicopsychidae, Philopotamidae).

The retreat of S. travertinera (Fig. 1B-D) differs from all known Smicridea retreats. Previously described Smicridea larvae construct typical hydropsychid retreats with capture nets (Flint 1974, Correa et al. 1981, Oliveira and Froehlich 1996, Wiggins 1996). Smicridea travertinera retreats consist of a structure amalgamated to the travertine matrix, with a capture net at the anterior end and a small orifice at the posterior end (Fig. 1B). Over time, retreats become covered with $\mathrm{CaCO}_{3}$ precipitate, forming an intricate network of tunnels within the travertine matrix (Fig. 1D).

In Quebrada El Charo, precipitation of $\mathrm{CaCO}_{3}$ crystals seems to foul $S$. travertinera nets (Fig. 1C), and larvae constantly rebuild and clean nets, presumably to reduce clogging. We hypothesize that the larvae also chew (i.e., hollow out) the travertine matrix to construct the retreat. Gut content analysis indicates that larvae ingest diatoms and plant detritus as well large amounts of $\mathrm{CaCO}_{3}$ crystals. We assume that crystals in larval guts result both from retreat building and net-cleaning activity.

\section{Discussion}

Similar to $S$. travertinera, another species of Hydropsychidae, Macrostemum carolina (Banks), also produces tunnel-like retreats. Wallace and Sherberger (1974) described the retreat of $M$. carolina as a network of tunnels and burrows gouged by the larvae into bark and surface wood of submerged tree limbs. The retreat of $S$. travertinera, like M. carolina, has a posterior opening that allows water to flow through the retreat, which aerates the gills and evacuates feces. Wallace and Sherberger (1974) also inferred that the flat, carinate head of M. carolina serves to direct water flow through the different chambers of the retreat and to protect against predators. We think that the flat, carinate head of $S$. travertinera has similar functions.

Using scanning electron microscopy, Drysdale (1998) observed that the size of the $\mathrm{CaCO}_{3}$ particles around the retreat aperture of an Australian Cheumatopsyche were comparable to the size of larval mouthparts, indicating intentional placement. The shape and structure of the aperture of the retreats of S. travertinera (Fig. 1C) also suggest that $\mathrm{CaCO}_{3}$ fragments are intentionally positioned by larvae, especially evident in the lip built around the rim of the anterior opening (Fig. 1C).

Continual retreat- and net-building activities of larvae contribute both to the deposition and erosion of travertines. Flint (1996) reported that pits gouged by Hydropsyche incommoda Hagen larvae into wooden bridge pilings eventually resulted in a loss of structural integrity and collapse of the pilings. Over time, the intricate network of tunnels and retreats of $S$. travertinera appears to become the major biotic component of the travertine matrix (Fig. 1D). The process of travertine alteration by $S$. travertinera as well as erosion by larval tunnels indicates both an active and passive contribution by larvae toward biogenesis of travertine formations (Drysdale 1999).

Apparently, S. travertinera larvae have specific flow requirements, which are achieved at the travertine barrage. If the upper border of the travertine barrage is heavily colonized, the complexity of the travertine surface increases and the velocity of the water decreases, favoring an increase in precipitation of $\mathrm{CaCO}_{3}$ crystals. This event appears to be cyclical, as increased microtopographical complexity likely also increases $\mathrm{CaCO}_{3}$ precipitation, building the height of the barrage until flow is directed elsewhere. At this point it appears that larvae stop colonizing that area. Water becomes redirected around the barrage and begins flowing rapidly over other substrates, exposing new areas for colonization and the building up of other barrages. This succession of events probably causes travertine barrages to grow taller and stream pools to deepen. 
There is little published information on the biology of tropical Smicridea. Oliveira and Froehlich (1996) examined gut contents, mesh size, and flight periods of an undetermined Smicridea from southeastern Brazil. The average mesh size of capture nets for the species in their study was $60 \times 68 \mu \mathrm{m}$, almost $2 \times$ larger than S. travertinera. Gut contents of larvae in their study were largely diatoms. Boon (1988) reported on the habitat and biology of 3 species of Smicridea from Jamaica. An undetermined species of Smicridea was the only one found inhabiting cascades with limestone substrate. Larvae of the Jamaican species appeared to burrow into the limestone substrate, but did not make the extensive excavations or retreats we report for $S$. travertinera. Mean mesh dimensions of the Jamaican species were $47 \mu \mathrm{m} \times 36 \mu \mathrm{m}$, and gut contents consisted of fine detritus and diatoms. We also found diatoms as one of the main components of the diet of $S$. travertinera, but guts of final instars were so clogged with $\mathrm{CaCO}_{3}$ crystals that all food appeared miniscule in comparison with ingested crystals. However, we believe that diatoms are a major food item for $S$. travertinera.

Studies of travertine-associated macroinvertebrates are extremely limited. Research on the ecology and behavior of macroinvertebrates inhabiting travertine formations is needed to understand how these organisms influence travertine geomorphology. Studies of microhabitat preference by aquatic insects, faunal composition of travertines, and rates of deposition and erosion of travertines, with or without a macroinvertebrate component, would greatly improve our understanding of environmental influences on travertine formations.

\section{Acknowledgements}

HP was supported by a PhD fellowship from CAPES (Coordenação de Aperfeiçoamento de Pessoal de Nível Superior), Brazilian Ministry of Education. We are grateful to INPARQUES for assistance with collecting permits, to Degnis Ramírez, Director, Parque Nacional Cueva de la Quebrada del Toro, and to park rangers César Adans, Alí Baldallo, and Delcis Reyes. We also thank Cézar Cordero for field assistance, Oliver S. Flint, Jr., for insightful comments and the loan of specimens, Kris Kuda for illustrating larvae, and Fernando Muñoz-Quesada, Roger Blahnik,
Terrence Ehrman, Russell Drysdale and 2 anonymous reviewers for valuable suggestions on the manuscript. This material is based upon work supported by the NSF grants DEB-9971885 and DEB-0117772. Additional support was provided by the University of Minnesota Insect Collection and the Dayton-Wilkie Fund, Bell Museum of Natural History.

\section{Literature Cited}

BLAHNIK, R. J. 1995. New species of Smicridea (subgenus Smicridea) from Costa Rica, with a revision of the fasciatella complex (Trichoptera: Hydropyschidae). Journal of the North American Benthological Society 14:84-107.

BooN, P. J. 1988. Notes on the distribution and biology of Smicridea (Trichoptera: Hydropsychidae) in Jamaica. Archiv für Hydrobiologie 111:423-433.

Correa, M., T. MACHADO, AND G. RoldÁN. 1981. Taxonomía y ecología del Orden Trichoptera en el Departamento de Antioquia en diferentes pisos altitudinales. Actualidades Biológicas 10:35-48.

DRYSDALE, R. N. 1998. Aquatic insect larvae as geomorphic agents in travertine-building: a case study from the Barkly Karst, Australia. Supplement Geografia Física Dinamica Quaternária 4: 53-59.

DRYSDALE, R. N. 1999. The sedimentological significance of hydropsychid caddis-fly larvae (Order: Trichoptera) in a travertine-depositing stream: Louie Creek, northwest Queensland, Australia. Journal of Sedimentary Research 69:145-150.

DRYSDALE, R. N. 2001. Factors controlling the hydrochemistry of Louie Creek, a travertine-depositing stream in the seasonally wet tropics of northern Australia. Marine and Freshwater Research 52: 793-804.

FLINT, O. S. 1974. Studies of Neotropical caddisflies, XVII: The genus Smicridea from North and Central America (Trichoptera: Hydropsychidae). Smithsonian Contributions to Zoology 167:1-65.

FLINT, O. S. 1981. Studies of Neotropical caddisflies, XXVIII: The Trichoptera of the Río Limón Basin, Venezuela. Smithsonian Contributions to Zoology 330:1-61.

FLINT, O. S. 1989. Studies of Neotropical caddisflies, XXXIX: The genus Smicridea in the Chilean Subregion (Trichoptera: Hydropsychidae). Smithsonian Contributions to Zoology 472:1-45.

FLINT, O. S. 1996. Caddisflies do count: collapse of the S.R. 675 bridge over the Pocomoke River, Pocomoke City, Maryland. Bulletin of the North American Benthological Society 13:376-383.

Flint, O. S., R. W. Holzenthal, and S. C. Harris. 1999. Catalog of the Neotropical Caddisflies (Insecta: Trichoptera). Ohio Biological Survey, Columbus, Ohio. 
Freytet, P., AND E. VerReCChIA. 1995. Discovery of Ca oxalate crystals associated with fungi in moss travertines (bryoherms, freshwater heterogeneous stromatolites). Geomicrobiology Journal 13:117127.

GABALDÓN, M. 1987. Venezuela un país sembrado de parques. Instituto Nacional de Parques (INPARQUES). Sede Principal de INPARQUES, Lado Sur del Museo de Tansporte, Distribuidor Santa Cecilia, Caracas, Venezuela.

GABALdón, M. 1992. Parques Nacionales de Venezuela. Serie Parques Nacionales y Conservación Ambiental. Instituto Nacional de Parques, Caracas, Venezuela.

Humphreys, W. F., S. M. AWramik, AND M. H. P. JebB. 1995. Freshwater biogenic tufa dams in Madang Province, Papua New Guinea. Journal of the Royal Society of Western Australia 78:43-54.

Oliveira, L. G., AND C. G. FroeHlich. 1996. Natural history of three Hydropsychidae (Trichoptera, Insecta) in a "Cerrado" stream from northeastern São Paulo, Brazil. Revista Brasileira de Zoologia 13:755-762.
Pentecost, A., S. Bayari, And C. Yesertener. 1997. Phototrophic microorganisms of the Pamukkale travertine, Turkey-their distribution and influence on travertine deposition. Geomicrobiology Journal 14:269-283.

Pentecost, A., AND H. A. Viles. 1994. A review and assessment of travertine classification. Géographie Physique et Quaternaire 48:305-314.

SCHMID, F. 1998. The insects and arachnids of Canada. Part 7. Genera of the Trichoptera of Canada and adjoining or adjacent United States. NRC Research Press, Ottawa, Ontario.

ThienEmAnN, A. 1933. Mückenlarven bilden Gestein. Natur und Museum, Senckenbergische Naturforschende Gesellschaft 63:370-378.

Wallace, J. B., AND F. F. SHerberger. 1974. The larval retreat and feeding net of Macronema carolina Banks (Trichoptera: Hydropsychidae). Hydrobiologia 45:177-184.

Wiggins, G. B. 1996. Larvae of the North American caddisfly genera (Trichoptera). 2nd edition. University of Toronto Press, Toronto, Ontario.

Received: 16 October 2002 Accepted: 12 June 2003 